УДК 303.005.31:338

DOI https://doi.org/10.32851/2708-0366/2021.7.13

Седікова I.O.

доктор економічних наук,

профресор кафредри менеджменту і логістики,

Одеська національна академія харчових технологій

ORCID: https//orcid.org/0000-0001-5684-6927

Дурбалова Н.I.

аспірантка кафедри менеджменту і логістики,

Одеська національна академія харчових технологій

ORCID: https://orcid.org/0000-0002-0739-1265

Новічков В.К.

кандидат географрічних наук,

доцент кафедри готельно-ресторанного бізнесу,

Одеська національна академія харчових технологій

Sedikova Iryna, Durbalova Natalia, Novichkov Viktor

Odessa National Academy of Food Technologies

\title{
СТРАТЕГІЧНЕ УПРАВЛІННЯ КОНКУРЕНТНИМ ПОТЕНЦІАЛОМ ПІДПРИЄМСТВ ХЛІБОПЕКАРСЬКОЇ ГАЛУЗІ
}

\section{STRATEGIC MANAGEMENT OF THE COMPETITIVE POTENTIAL OF BAKERY INDUSTRY ENTERPRISES}

Стратегічне управління забезпечує досягнення стійких конкурентних переваг на всіх етапах розвитку підприємства, розглядаючи та застосовуючи процесуальний, структурний, змістовний, людський, ринковий та ресурсний аспекти. Проаналізовано ринок хліба та хлібобулочних виробів та виявлено основні тенденції його функціонування. Доведено, щуо підгрунтям підвищення конкурентного потенціалу підприємства є управління стратегічними активами і компетенціями підприємства. Здійснено аналіз конкурентного потенціалу підприємств хлібопекарської галузі Одеської області. Проаналізовано складові елементи конкурентного потениіалу. Аналіз рівня та динаміки потениіалу основних бізнес-проиесів виявив групу підприємств, у яких спостерігаються проблеми у виробничій сфері, пов'язані з відсутністю гнучких виробничих процесів, автоматизованих систем управління, із низькою узгодженістю систем постачання $i$ збуту. Розраховано рівень конкурентного потенціалу, який дав змогу визначити конкурентну позицію підприємства та розрахувати індекс фактичного використання конкурентного потенціалу.

Ключові слова: потенціал, стратегія, конкуренція, хліб, ринок хлібу, стратегічне управління, конкурентні переваги.

Стратегическое управление обеспечивает достижение устойчивых конкурентных преимушеств на всех этапах развития предприятия, рассматривая и применяя процессуальный, сттруктурный, рыночный, ресурсный аспекты. Проанализирован рынок хлеба и хлебобулочных изделий и выявлены основные тенденции его функционирования. Доказано, что основой повышения конкурентного потенциала является управление стратегическими активами и компетенциями предприятия. Проведен анализ конкурентного потенцииала предприятий хлебопекарной отрасли Одесской области. Проанализированы основные элементы конкурентного потенциала. Анализ уровня и динамики потенщиала основных бизнес-процессов выявил группу предприятий, у которых наблюдаются проблемь в производственной сфере, связанные с отсутствием гибких производственных процессов, автоматизированных систем управления, низкой согласованностью систем снабжения и сбыта. Рассчитан уровень конкурентного потенциала, который позволил определить конкурентную позицию предприятия и рассчитать индекс фактического использования конкурентного потеничала.

Ключевые слова: потенциал, стратегия, конкуренция, хлеб, рынок хлеба, стратегическое управление, конкурентные преимущества. 
The article analyzes the mechanisms for ensuring sustainable competitive advantages of the bakery industry. It is determined that strategic management ensures the achievement of sustainable competitive advantages at all stages of the enterprise life cycle, considering and applying procedural, structural, substantive, human, market and resource aspects. A digression around the definitions of the concept of "competitive potential" allowed us to formulate our own definition. From the authors' point of view, competitive potential is the ability of a business to create long-term competitive advantages and adequately respond to changes in the competitive environment.

The market of bread and bakery products is analyzed and the main tendencies of its functioning are revealed, namely, in recent years the tendency of rise in price of bread with increase in prices for raw materials is traced, there was a rise in price of "bread basket" in 4 times, steady decrease in production. It is determined that one of the main problems of the market is the presence of a large shadow segment, which hinders the development of fair competition. It is proved that the basis for increasing the competitive potential of the enterprise is the management of strategic assets and competencies of the enterprise. In this study, an analysis of the competitive potential of enterprises in the bakery industry of Odessa region. The analysis of the constituent elements of the competitive potential is carried out and the main tendencies are revealed. The dynamics of financial potential indicates a high level of instability in the formation of financial resources. The analysis of the level and dynamics of the potential of the main business processes revealed a group of enterprises with problems in the production sphere due to the lack of flexible production processes, automated management systems, low consistency of supply and marketing systems.

The possible level of competitive potential was calculated in the work, which reflects the creation of the maximum sustainable competitive advantages of the enterprise. This allowed us to determine the current competitive position of the enterprise and calculate the index of the actual use of competitive potential.

Key words: potential, strategy, competition, bread, bread market, strategic management, competitive advantage.

Постановка проблеми. Дослідження конкурентного потенціалу підприємства як важливого складника національної економіки набуває особливо значення в сучасних умовах економічного розвитку країни, умовах зростаючої ролі споживачів, ризиків та невизначеності мінливого зовнішнього середовища. Вирішення проблем формування та управління конкурентним потенціалом підприємств на ринку є однією 3 функцій стратегічного управління. За суттю, важливо розглядати конкурентний потенціал підприємств як невід'ємну частину середньо- та довгострокового сталого розвитку. Однією з галузей, пов'язаних із формуванням системи стратегічного управління конкурентними перевагами, є харчова промисловість, зокрема хлібопекарська.

Аналіз останніх досліджень і публікацій. Теоретичні й практичні аспекти формування базових та функціональних стратегій підприємств знайшли відображення в роботах зарубіжних дослідників: І. Ансоффа, Ф. Котлера, Ж.-Ж. Ламбена, М. Мескона, М. Портера, А.Дж. Стрікленда, А.А. Томпсона та ін. Питанням поліпшення конкурентного потенціалу підприємств хлібопекарської галузі присвячені праці вітчизняних науковців Б. Артем’єва, Є. Лапіна, О. Шпака, А. Андрейченка, В. Геєця, М. Маліка, В. Мочерного, О. Нікішиної, П. Саблука, Т. Федорової, О. Шпичака та ін. Однак сучасні детермінанти розвитку хлібопекарської галузі вимагають подальшого вдосконалення наукових і практичних механізмів щодо стратегічного управління конкурентним потенціалом підприємств, тому тема даного дослідження $є$ актуальною.

Формулювання цілей статті. Метою дослідження є розроблення та наукове обгрунтування методів та інструментарію управлення конкурентним потенціалом підприємств хлібопекарської галузі.

Виклад основного матеріалу. Управління конкурентоспроможністю полягає у формуванні певного рівня конкурентного потенціалу та його підтримці. Управління конкурентним потенціалом передбачає формування довгострокових стійких конкурентних переваг. Прослідковується чіткий взаємозв'язок між управлінням конкурентоспроможністю та стратегічним управлінням. Стратегічне управління повинне забезпечити ефективну життєдіяльність підприємства. Це означає його збереження 
як суб'єкта господарювання в системі існуючих чинників, створення умов зростання, розвитку, підтримки стійкості. При цьому чинники зовнішнього та внутрішнього середовища можуть сприяти як розвитку, так і руйнуванню підприємства. Стратегічне управління забезпечує досягнення стійких конкурентних переваг на всіх етапах життєвого циклу підприємства, розглядаючи та застосовуючи процесуальний, структурний, змістовний, людський, ринковий та ресурсний аспекти.

Сучасний погляд стосовно внутрішніх конкурентних переваг висвітлює у своїх роботах Р. Фахрутдінов [1]. Він поділяє внутрішні конкурентні переваги підприємства на шість груп, а саме: структурні, ресурсні, технічні, управлінські, ринкові, ефективність функціонування підприємства. Автори дослідження погоджуються 3 думкою I. Довжанського [2], що «внутрішні конкурентні переваги формуються в результаті діяльності підприємства і носіями таких переваг можуть бути передусім чинники виробничої, фінансової та інноваційної діяльності підприємства» [2].

На думку А. Градова [3], необхідно розмежовувати поняття внутрішніх переваг (конкурентних позицій) і ринкових конкурентних переваг (конкурентного статусу), у першу чергу, за ступенем впливу підприємства на ті чинники, які визначають конкурентні та ринкові переваги підприємства. Якщо внутрішні переваги підприємства у виробництві, фінансах, ресурсах формуються за можливостями підприємства, то чинники, ринкової переваги знаходяться під впливом конкурентів, споживачів, постачальників тощо [3].

О. Ульянченко [4] визначає, що «в умовах бурхливого розвитку зовнішнього середовища і ринкової ситуації перемогу в конкурентній боротьбі може отримати не обов'язково підприємство 3 великими обсягами виробництва та стійкими фінансовими позиціями, а навіть невелика фірма, яка може більш оперативно адаптуватися до змін зовнішнього середовища» [4].

Спираючись на інституційний підхід, конкурентний потенціал можна визначити як сукупну здатність підприємства використовувати внутрішні фінансово-інвестиційні, виробничі, інноваційні та людські ресурси з метою створення стійких конкурентних переваг. Здійснений екскурс навколо дефініцій означеного поняття [5;6; 3; 7-9] дав змогу сформулювати власне визначення. Із точки зору авторів, конкурентний потенціал - це здатність бізнесу створювати довгострокові конкурентні переваги й адекватно реагувати на зміни в конкурентному середовищі.

Хлібопекарна галузь України є однією з провідних галузей харчової промисловості України, місія якої полягає у безперебійному виробництві соціально значущих товарів повсякденного попиту. Хліб і хлібобулочні вироби є одним зі стратегічних напрямів держави. Вони становлять $40 \%$ калорійності раціону українців. Ринок має розгалужену територіальну й регіональну охопленість - хлібопекарські підприємства функціонують в усіх областях України. Нині серед промислових виробників хліба та хлібобулочних виробів основна частка припадає на вертикально інтегровані компанії (рис. 1).

Слід зазначити, що діюча структура операторів ринку диференційована: промислове виробництво продукції - 39\%, міні-пекарні та пекарні торговельної мережі 54\%, цехи підприємств громадського та швидкого харчування - 8\% [11]. Незважаючи на свою значимість, у галузі спостерігаються негативні процеси: протягом останніх чотирьох років обсяги ринку падають через падіння попиту в основному сегменті [11].

Ринок характеризується тенденцією подорожчання хліба зі збільшенням цін на сировинні складники: борошно, цукор, яйця, олієжирову продукцію, а також зростанням цін на енергоносії та паливно-мастильні матеріали. За 2019 р. ціни на хліб піднялися на 18\% порівняно з 2018 р., тоді як інфляція в Україні за рік становила 4\%, тобто подорожчання «хлібного кошика» відбулося більше ніж у чотири рази швидше зростання середнього рівня цін у країні [11]. 


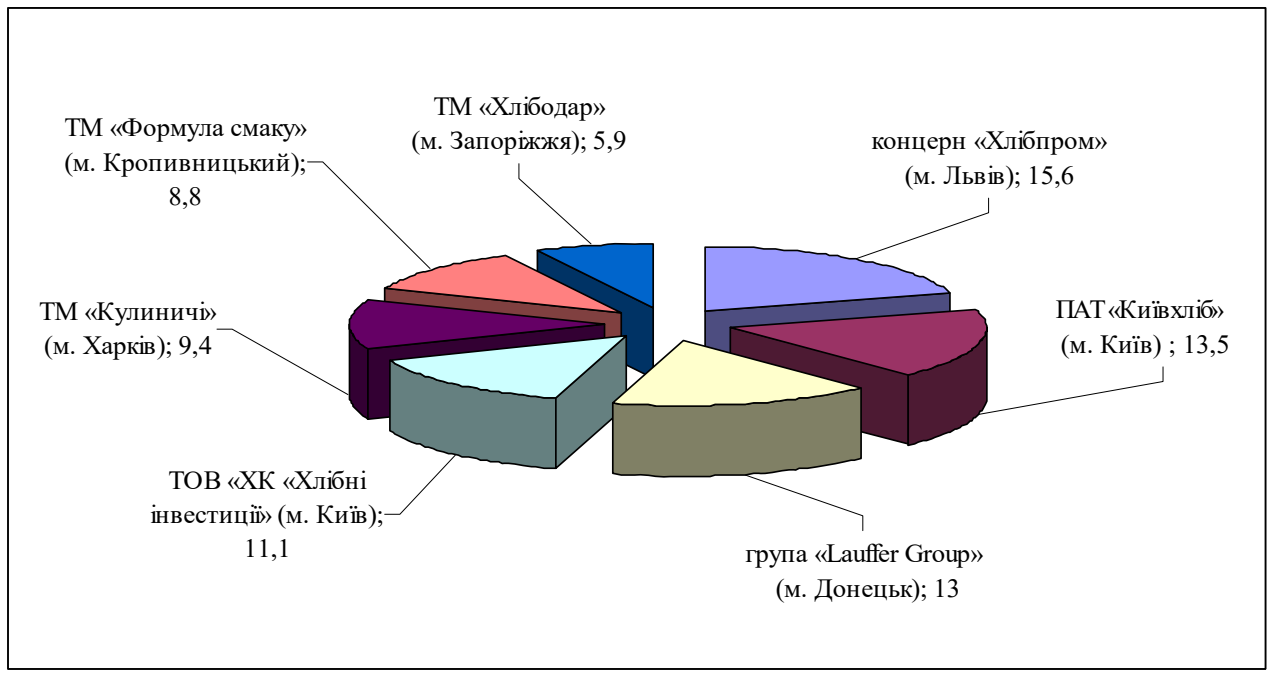

Рис. 1. Частка вертикально інтегрованих компаній на ринку хліба та хлібобулочних виробів

Джерело: побудовано авторами на основі [10]

За останні чотири роки спостерігалося стабільне зменшення виробництва. Однією з головних проблем ринку є наявність великого тіньового сегмента, який перешкоджає розвитку справедливої конкуренції. На ринку представлена продукція вітчизняного виробництва, що пов'язано з короткими термінами зберігання і складністю транспортування. Більшість населення купує традиційні види хліба. У великих містах набули популярності багети та інші види хліба: білковий, бездріжджовий, із добавками. Рейтинг споживчих переваг щороку має приблизно одні й ті ж значення.

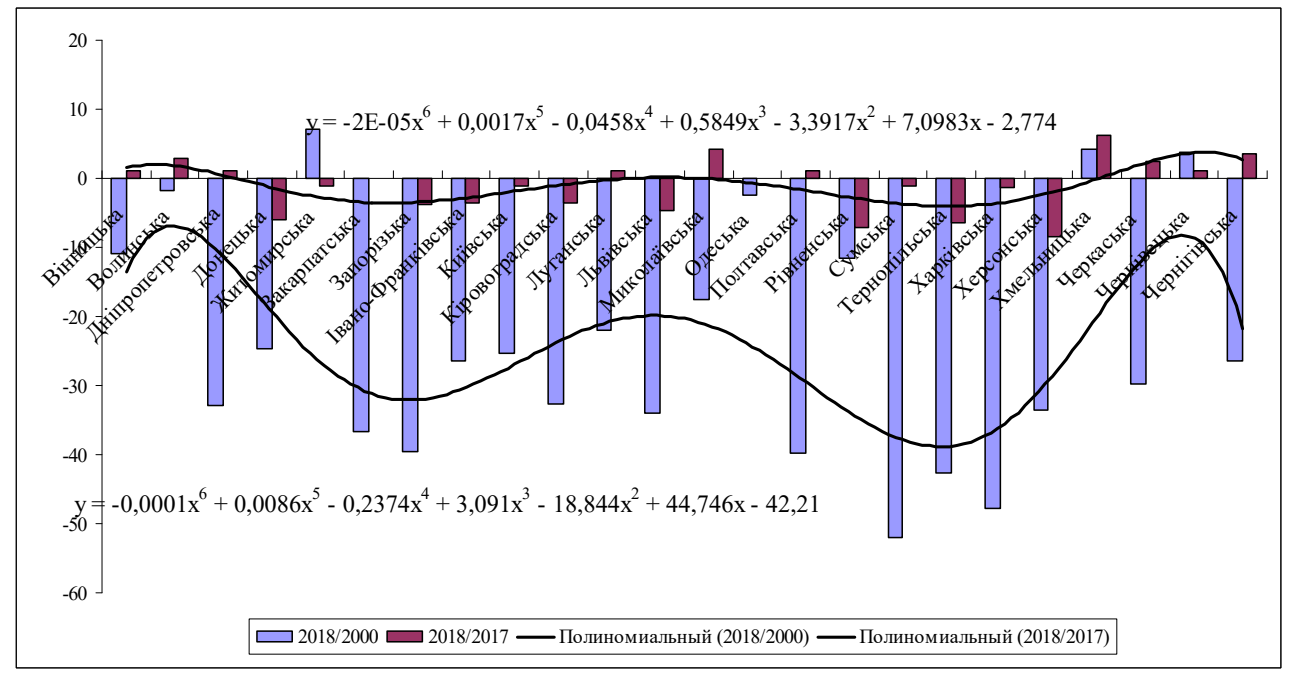

Рис. 2. Динаміка зниження обсягів та споживання хліба та хлібобулочних виробів, 2000-2018 рр.

Джерело: побудовано авторами на основі [11] 
Вітчизняні підприємства прагнуть виробляти все більше нових продуктів, зростає популярність на нетрадиційні сорти хліба. Компаніям усе більше необхідно звертати увагу на максимальну «природність» продукції, щоб утримуватися в лідерах із продажу у зв'язку з ростом попиту серед споживачів на продукти здорового харчування [11].

Орієнтованість різних груп виробників на різні сегменти ринку хліба та хлібобулочні виробі наведено в табл. 1. Як видно, три групи учасників ринку мають різну орієнтацію на сегменти ринку. Це зумовлено їхніми конкурентними перевагами, співвідношенням сильних та слабких боків підприємства.

Таблиця 1

\section{Оріснтація учасників ринку хліба та хлібобулочних виробів} на ринкові сегменти

\begin{tabular}{|c|c|c|c|}
\hline Сегменти ринка & $\begin{array}{l}\text { Традиційні } \\
\text { виробники }\end{array}$ & $\begin{array}{c}\text { Роздрібні } \\
\text { торгівельні мережі }\end{array}$ & $\begin{array}{c}\text { Міні- } \\
\text { пекарні }\end{array}$ \\
\hline \multicolumn{4}{|l|}{ 1. За видами продукції } \\
\hline 1.1. Хліб & 1 & 2 & 2 \\
\hline 1.2. Батони & 1 & 1 & 1 \\
\hline 1.3. Дрібноштучні та здобні вироби & 2 & 2 & 1 \\
\hline $\begin{array}{l}\text { 1.4. Хлібобулочні вироби з корисними } \\
\text { добавками }\end{array}$ & 2 & 1 & 2 \\
\hline \multicolumn{4}{|l|}{ 2. За ціновими категоріями } \\
\hline $\begin{array}{l}\text { 2.1. Регульовані ціни на хліб «соціального» } \\
\text { попиту (соціально значущі сорти хлібу) }\end{array}$ & 1 & 2 & 2 \\
\hline $\begin{array}{l}\text { 2.2. Нерегульовані ціни на нетрадиційні } \\
\text { хлібобулочні вироби }\end{array}$ & 2 & 1 & 1 \\
\hline \multicolumn{4}{|l|}{ 3. За рівнями ринку } \\
\hline 3.1. Локальні ринки & 1 & 2 & 1 \\
\hline 3.2. Регіональні ринки & 2 & 1 & 3 \\
\hline 3.3. Національні ринки & 3 & 1 & 3 \\
\hline
\end{tabular}

1 - основна ніша; 2 - не основна ніша; 3 - виробник у даному сегменті не представлений

\section{Джерело: власна розробка}

Підгрунтям підвищення конкурентного потенціалу підприємства є управління стратегічними активами і компетенціями підприємства. Класичне уявлення про стратегічні активи свідчить, що це ресурси, які за своїми параметрами перевершують аналогічні ресурси конкурентів. Стратегічні компетенції традиційно розглядаються як стратегічно значущі для бізнес-одиниці вектори діяльності, в яких вона найбільш сильна. Стійкі конкурентні переваги грунтуються на використанні сильних боків підприємства чи слабких боків конкурентів або на нейтралізації слабких боків підприємства чи сильних боків конкурентів.

У даному дослідженні здійснено аналіз конкурентного потенціалу підприємств хлібопекарської галузі Одеської області. Регіональне розміщення у галузі виробництва хліба і хлібобулочних виробів Одеської області наведено на рис. 3.

Конкурентний потенціал досліджуваних хлібопекарських підприємств Одеської області за 2016-2019 рр. наведено в табл. 2.

Як бачимо $з$ табл. 2, діапазон коливань конкурентного потенціалу підприємств $є$ достатньо широким. Аналіз складових елементів конкурентного потенціалу дав змогу виявити такі тенденції. 


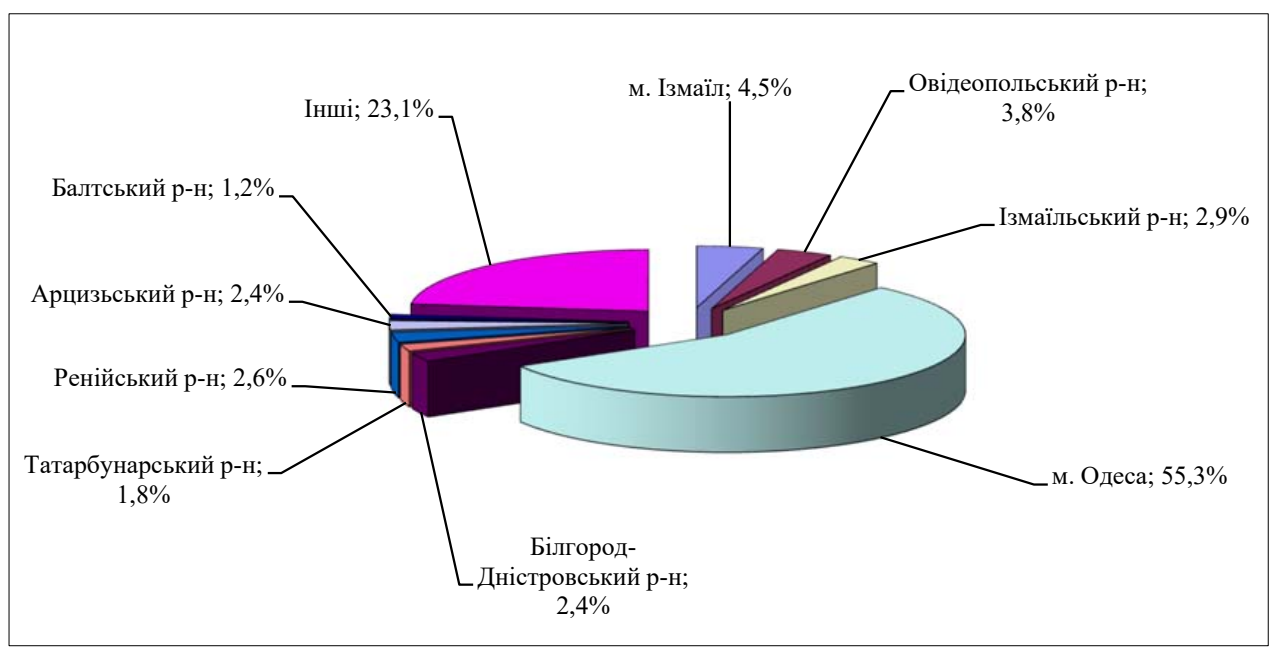

Рис. 3. Регіональне розмішення у галузі виробнищтва хліба і хлібобулочних виробів Одеської області

Джерело: побудовано авторами на основі [12]

Таблиця 2

Конкурентний потенціал хлібопекарських підприємств Одеської області

\begin{tabular}{|l|c|c|c|c|c|c|}
\hline \multicolumn{1}{|c|}{ Найменування підприємства } & $\mathbf{2 0 0 1 6}$ & $\mathbf{2 0 1 7}$ & $\mathbf{2 0 1 8}$ & $\mathbf{2 0 1 9}$ & $\mathbf{2 0 2 0}$ & Середнє \\
\hline Нове Діло, ТОВ & 30,145 & 28,519 & 30,710 & 32,307 & 32,531 & 30,842 \\
\hline $\begin{array}{l}\text { Білгород-Дністровська паляниця, } \\
\text { тОВ }\end{array}$ & 35,224 & 34,661 & 36,648 & 35,644 & 36,456 & 35,726 \\
\hline Одеський коровай, ПрАТ & 38,373 & 39,614 & 41,712 & 44,561 & 44,136 & 41,679 \\
\hline Котовський хлібозавод, ТОВ & 31,758 & 31,882 & 33,134 & 31,295 & 32,559 & 32,125 \\
\hline Южненська паляниця, КП & 37,996 & 38,446 & 38,796 & 40,792 & 41,970 & 39,600 \\
\hline Квінт-Л, ТОВ & 28,215 & 29,556 & 31,609 & 33,442 & 34,270 & 31,418 \\
\hline $\begin{array}{l}\text { Ренійський хлібозавод } \\
\text { «Дунай-коровай», ТОВ }\end{array}$ & 38,807 & 38,439 & 38,358 & 40,980 & 40,743 & 39,465 \\
\hline Глобус-Плюс, ТОВ & 32,330 & 35,671 & 35,714 & 36,201 & 38,016 & 35,587 \\
\hline УкрХліб-2, ПП & 41,828 & 38,875 & 40,339 & 41,689 & 42,380 & 41,022 \\
\hline Болградський хлібозавод, ТОВ & 33,717 & 34,561 & 38,027 & 37,985 & 41,387 & 37,136 \\
\hline Ананьїв-Хліб, ПП & 40,462 & 42,574 & 43,638 & 45,290 & 47,706 & 43,934 \\
\hline ВКФ, Одеса-Хліб М, ПП & 37,925 & 36,806 & 39,038 & 38,150 & 39,489 & 38,282 \\
\hline
\end{tabular}

Джерело: побудовано авторами

Динаміка фінансового потенціалу свідчить про високий рівень нестабільності формування фінансових ресурсів. Аналіз рівня та динаміки потенціалу основних бізнес-процесів виявив групу підприємств, у яких спостерігаються проблеми у виробничій сфері, пов'язані з відсутністю гнучких виробничих процесів, автоматизованих систем управління, низькою узгодженістю систем постачання і збуту. До цієї групи нами віднесено: Ренійський хлібозавод «Дунай-коровай», ТОВ, ВКФ, «Одеса-Хліб М», ПП, Котовський хлібозавод, ТОВ. Найбільш сильні стратегічні позиції в орга- 
нізації основних бізнес-процесів мають Ренійський хлібозавод «Дунай-коровай», «Ананьїв-Хліб», «Одеський коровай».

Відносно трудового потенціалу також спостерігається нестабільна ситуація за винятком низки підприємств. Це зумовлено низьким рівнем мотиваційного складника i, відповідно, низькою продуктивністю праці. Оцінка управлінського потенціалу свідчить, що найбільш чітко вибудована система управління на таких підприємствах, як «Білгород-Дністровська паляниця», «УкрХліб - 2», «Глобус-Плюс», «Ананьїв-Хліб». На цих підприємствах постійно вдосконалюється система менеджменту, впроваджуються елементи стратегічного управління, довгострокового планування і бюджетування. Рівень інноваційного потенціалу у більшості проаналізованих підприємств хлібопекарської промисловості має тенденцію до зростання. Хлібопекарські підприємства нині здійснюють інвестиції в інноваційне технологічне розроблення нових рецептур, переважно в кондитерському виробництві.

У роботі був розрахований можливий рівень конкурентного потенціалу, який відображає створення максимальних стійких конкурентних переваг підприємства. Це дало змогу визначити поточну конкурентну позицію підприємства та розрахувати індекс фактичного використання конкурентного потенціалу (табл. 3).

Таблиця 3

Індекси фактичного використання конкурентного потенціалу на хлібопекарських підприємствах Одеської області

\begin{tabular}{|l|c|c|c|c|c|c|}
\hline \multicolumn{1}{|c|}{ Найменування підприсмства } & $\mathbf{2 0 0 1 6}$ & $\mathbf{2 0 1 7}$ & $\mathbf{2 0 1 8}$ & $\mathbf{2 0 1 9}$ & $\mathbf{2 0 2 0}$ & Середнє \\
\hline Нове Діло, ТОВ & 0,496 & 0,469 & 0,505 & 0,531 & 0,535 & 0,507 \\
\hline Білгород-Дністровська паляниця, ТОВ & 0,579 & 0,570 & 0,603 & 0,586 & 0,599 & 0,587 \\
\hline Одеський коровай, ПрАТ & 0,631 & 0,651 & 0,686 & 0,733 & 0,726 & 0,722 \\
\hline Котовський хлібозавод, ТОВ & 0,625 & 0,632 & 0,638 & 0,671 & 0,690 & 0,651 \\
\hline Южненська паляниця, КП & 0,464 & 0,486 & 0,520 & 0,550 & 0,563 & 0,517 \\
\hline Квінт-Л, ТОВ & 0,638 & 0,632 & 0,631 & 0,674 & 0,670 & 0,649 \\
\hline $\begin{array}{l}\text { Ренійський хлібозавод «Дунай-коровай», } \\
\text { ТОВ }\end{array}$ & 0,532 & 0,586 & 0,587 & 0,595 & 0,625 & 0,585 \\
\hline Глобус-Плюс, ТОВ & 0,688 & 0,639 & 0,663 & 0,685 & 0,697 & 0,674 \\
\hline УкрХліб - 2, ПП & 0,522 & 0,524 & 0,545 & 0,515 & 0,535 & 0,528 \\
\hline Болградський хлібзавод, ТОВ & 0,554 & 0,568 & 0,625 & 0,625 & 0,680 & 0,611 \\
\hline Ананьїв-Хліб, ПП & 0,665 & 0,700 & 0,717 & 0,745 & 0,784 & 0,685 \\
\hline ВКФ, Одеса-Хліб М, ПП & 0,624 & 0,605 & 0,642 & 0,627 & 0,649 & 0,629 \\
\hline
\end{tabular}

Джерело: побудовано авторами

Як видно з табл. 3, індекси фактичного використання конкурентного потенціалу в середньому коливаються від 0,507 («Нове Діло», ТОВ) до 0,722 («Одеський коровай», ПрАТ). Таким чином, підприємства мають різний рівень використання конкурентного потенціалу, тому необхідне розроблення різних стратегій, які забезпечують формування стійких конкурентних переваг.

Висновки. Для підприємств, що мають високий рівень використання конкурентного потенціалу, можна запропонувати стратегію економії на витратах на основі максимально повного використання ефекту масштабу виробництва, тобто впроваджувати стратегію концентрації у сегменті соціально значущих сортів хліба.

Для підприємств, що мають середній рівень використання конкурентного потенціалу, доцільно використовувати стратегію інтеграції (виробництво і реалізацію напів- 
фабрикатів для міні-пекарень). Підприємства з низьким рівнем використання конкурентного потенціалу повинні орієнтуватися на стратегію диференціації (фітнес-лінії, дієтичні види хліба, збагачені та лікувальні сорти).

Однією з ключових стратегій розвитку галузі, що забезпечує стійкі конкурентні переваги, повинна стати нішева стратегія. Управління стійкими конкурентними перевагами підприємств хлібопекарських підприємств має бути пов'язане саме 3 продуктовим складником. Підприємства повинні орієнтуватися, перш за все, на перший сегмент соціально значимих сортів хліба. У цьому сегменті у великих підприємств є незаперечні конкурентні переваги. До їх числа можна віднести державну власність, високу якість хліба. виконання великих замовлень на виробництво хліба.

\section{Список використаних джерел:}

1. Фахрутдинов Р.А. Конкурентоспособность: экономика, стратегия, управление. Москва : ИНФРА, 2010. $312 \mathrm{c}$.

2. Должанський І.З. Управління потенціалом підприємства : навчальний посібник. Київ : Центр навчальної літератури, 2016. 362 с.

3. Градов А. Економічна стратегія фірми. Київ : Спец. література, 2011. 415 с.

4. Ульянченко О.В. Конкурентоспроможність сільськогосподарських підприємств та стратегічні аспекти їі формування : монографія. Харків : Апостроф, 2011. 340 с.

5. Клименко С.М. Управління конкурентоспроможністю підприємства : навчальний посібник. Київ : КНЕУ, 2018. 527 с.

6. Євчук Л.А. Формування конкурентних переваг сільськогосподарськими підприємствами. URL: http://www.rusnauka.com/21_DNIS_2009/ Economics/49529.doc (дата звернення: 12.05.2021).

7. Лепьохін О.В. Концепція ефективного менеджменту конкурентоспроможності підприємств. Інвестииї̈: практика та досвід. 2019. № 3. С. 27-39.

8. Обідіна Я.І. Методологічні основи підвищення конкурентоспроможності хлібопекарських підприємств. Суми : Мрія - I. 2019. 61 с.

9. Федорова Т.В. Формування конкурентних переваг підприємств хлібопекарської галузі. Формування ринкової економіки. Київ, 2017. С. 143-151.

10. Рынок хлеба Украины. РБК-Украина. URL: http:/www. RetailStudio.org (дата звернення: 12.05.2021).

11. Аналітика, дослідження ринків. URL: http://surl.li/vmtz (дата звернення: 12.05.2021).

12. Стратегія розвитку Одеської області на період 2021-2027 pp. URL: http://surl.li/vmub (дата звернення: 12.05.2021).

\section{References:}

1. Fakhrutdynov R. (2010) Konkurentosposobnost: ekonomyka, stratehyia, upravlenye [Competitiveness: economics, strategy, management]. Moscow: YNFRA. (in Russian)

2. Dolzhanskyi I. (2016) Upravlinnia potentsialom pidpryiemstva [Enterprise potential management]. Kyiv: Tsentr navchalnoi literatury. (in Ukrainian)

3. Hradov A. (2011) Ekonomichna stratehiia firmy [Economic strategy of the firm]. Kyiv. Special literature. (in Ukrainian)

4. Ulianchenko O. (2011) Konkurentospromozhnist silskohospodarskykh pidpryiemstv ta stratehichni aspekty yii formuvannia [Competitiveness of agricultural enterprises and strategic aspects of its formation. Kharkiv: «Apostrof». (in Ukrainian)

5. Klymenko S. (2018) Upravlinnia konkurentospromozhnistiu pidpryiemstva [Enterprise competitiveness management]. Kyiv: KNEU. (in Ukrainian)

6. Yevchuk L. (2019) Formuvannia konkurentnykh perevah silskohospodarskymy pidpryiemstvamy [Formation of competitive advantages by agricultural enterprises]. Available at: http://surl.li/ vmtm.

7. Lepokhin O. (2019) Kontseptsiia efektyvnoho menedzhmentu konkurentospromozhnosti pidpryiemstv [The concept of effective management of enterprise competitiveness]. Investments: practice and experience, vol. 3, pp. 27-39. 
8. Obidina Ya. (2019) Metodolohichni osnovy pidvyshchennia konkurentospromozhnosti khlibopekarskykh pidpryiemstv [Methodological bases of increasing the competitiveness of bakery enterprises]. Sumy: Publishing and production enterprise «Dream-I» Ltd. (in Ukrainian)

9. Fedorova T. (2017) Formuvannia konkurentnykh perevah pidpryiemstv khlibopekarskoi haluzi. Formuvannia rynkovoi ekonomiky [Formation of competitive advantages of bakery enterprises. Formation of a market economy]. Kyiv: KNEU. (in Ukrainian)

10. RBK-Ukrayna. Ynformatsyonnoe ahenstvo Rinok khleba Ukrayni [RBC - Ukraine. News Agency Bread Market of Ukraine]. Available at: http:/www.retailStudio.org.

11. Analytics, market research. Available at: http://surl.li/vmtz.

12. Stratehiia rozvytku Odeskoi oblasti na period 2021-2027 roky [Development strategy of Odessa region for the period 2021-2027 years]. Available at: http://surl.li/vmub. 